\title{
Genetic relationships in different sheep populations of Bangladesh based on microsatellite markers
}

\author{
M. Y. A. Khan ${ }^{1}$, S. S. Husain ${ }^{1}$, M. R. Alam², A. Teneva ${ }^{3}$, J. L. $\operatorname{Han}^{4}$ and M. O. Faruque ${ }^{1}$ \\ ${ }^{1}$ Department of Animal Breeding and Genetics, Bangladesh Agricultural University, Mymensingh-2202, Bangladesh, \\ ${ }^{2}$ Department of Animal Science, Bangladesh Agricultural University, Mymensingh-2202, Bangladesh, ${ }^{3}$ Department of \\ Genetics, University of Forestry 10,St.KI.Ochridsky Blvd, 1756 Sofia, Bulgaria and ${ }^{4}$ CAAS-ILRI Joint Laboratory on \\ Livestock and Forage Genetic Resources, Institute of Animal Science, Chinese Academy of Agricultural Sciences \\ (CAAS), Beijing 100193, China
}

\begin{abstract}
The genetic variation and differentiation among different populations of sheep in Bangladesh were studied by using 18 microsatellite markers. A total of 140 samples- 37 from Bangladesh Central (BGC), 40 from Bangladesh East (BGE), 39 from Bangladesh North (BGN) and 24 from Garole (GAR) were genotyped. The allele number per locus ranged from 2 to 10 . The average number of alleles per population was $5.50 \pm 1.72,5.33 \pm 2.00,6.39 \pm 2.06$ and $4.72 \pm 1.71$ for BGC, BGE, BGN and GAR respectively. Heterozygosity was found in the range from $0.5084 \pm 0.0187$ (BGE) to $0.5810 \pm 0.0237$ (GAR). The genetic distance $\left(D_{A}\right)$ between $B G N$ and GAR was the highest $(0.1071)$ and that between BGC and BGN was the lowest (0.0664). In the phylogenetic dendrogram, BGC and BGN grouped in the same cluster, while BGE and GAR formed another two separate clusters. The results indicate that all four sheep populations had rich genetic diversity and the Garole sheep (GAR) is considered as an independent breed in Bangladesh.
\end{abstract}

Keywords: Sheep, Microsatellite marker, Genetic relation, Phylogenetic dendrogram

\section{Introduction}

The sheep is one of important ruminant species in the world. Of the total sheep population, $64.43 \%$ of sheep are found in Asia and Africa. There are about 920 breeds, of which 233 are found in Asia (FAO, 2003). Sheep stand third in number among the ruminant species in Bangladesh and are used primarily for meat production. Bangladesh possesses 1.69 million sheep at present (BBS, 2004). Though the sheep was localized in particular areas of the country, they are now found all over the country. Most of the sheep of Bangladesh are indigenous in nature with few crossbreds (Bhuiyan, 2006). These animals were neglected in the past. Government has come forward to improve their productivity. The characterization of indigenous animals in term of phenotypes and genotypes is the first and prerequisite criteria for improving the animals genetically. Several studies have so far been conducted on morphological and genetic characteristics of Bangladeshi sheep populations (Tsunoda et al., 1984; Rahman, 1989; Sahana et al., 2001). The indigenous sheep of Bangladesh was first characterized by Tsuenoda et al. (1984) using isozymes. No work has yet been done to characterize the indigenous sheep using DNA markers especially microsatellites. However, this has been done in India by Mukesh et al. (2006) for Garole, Nila and Chokla sheep and by Arora and Bhatia (2006) for other sheep breeds. Microsatellite markers for sheep genotyping have also been used in other parts of the world by many investigators (Forbes et al., 1995; Grigaliunaite et al., 2003; Radko et al., 2006). The present study was, therefore, set to find out the genetic relations in Bangladeshi sheep using microsatellite markers.

\section{Materials and Methods}

\section{Sample collection, DNA extraction, and quantification}

All the sheep of Bangladesh were divided into four populations based on geographical distribution and history of breeding and management systems. These were Bangladesh East (BGE) representing the sheep of eastern part (Bandarban, Sylhet, Moulovibazar and Noakhali district), Bangladesh Central (BGC) and Bangladesh North (BGN) representing the sheep of central (Mymensingh and Tangail district) and northern part (Pabna, Chapainawabgonj, Gibandha and Chuadanga districts) of Bangladesh where introgression of some exotic genes have occurred, and (GAR) representing Garole sheep found in the area adjacent to Sundarban forest (Satkhira district). A total of 160 blood samples were collected from the four groups, taking 40 samples for each population. Samples were collected only from adult sheep of subsistent farmers taking a ratio of 1:3 for male and female. Samples were collected avoiding related animals. Blood was collected in venoject tube, treated with anticoagulant and carried to Animal Genetics Laboratory of Bangladesh Agricultural University and preserved at $4^{\circ} \mathrm{C}$ until DNA extraction. DNA was extracted following a salting out protocol after IAEA (2004). The DNA samples were quantified in $0.8 \%$ agarose gel electrophoresis. 
Microsatellite polymorphism detection

Polymerase Chain Reaction amplification and genotyping work were done in CAAS-ILRI joint laboratory in Beijing. All of 140 DNA samples were amplified in GeneAmp PCR system 9700 PCR machine using 18 pairs of microsatellite primers selected from FAO recommendation. All the microsatellite markers were forwardly labeled with a capillary based dye: 6FAM (blue), PET (Red), VIC (Green) and NED (yellow) for the purpose of genotyping. The PCR condition has been presented in Table 1. PCR was carried out in $15 \mu \mathrm{l}$ reaction mixture containing $4 \mathrm{ng} / \mu \mathrm{l}$ of template DNA, $0.3 \mu \mathrm{l}$ each $10 \mu \mathrm{M}$ primer, $1 \mu \mathrm{l}$ of $20 \mathrm{mM} \mathrm{dNTPs}$, $0.05 \mathrm{unit} / \mu \mathrm{l}$ of Taq DNA polymerase, 1.2 to $1.5 \mathrm{mM} / \mu \mathrm{l}$ of $\mathrm{MgCl}_{2}$ and $1 \mathrm{X}$ PCR buffer. All PCR products were quantified by $2 \%$ agarose gel electrophoresis for checking the success of PCR amplification. The amplified DNA was genotyped by automated capillary DNA sequencer Genetic Analyzer 3130xI of Applied Biosystem. The internal standard was prepared by adding $7.55 \mu \mathrm{l}$ of LIZ standard to $0.45 \mu \mathrm{l}$ of HiDi formamide. A total of $2 \mu \mathrm{l}$ of diluted PCR product of each co-loading was transferred to individual wells with $8 \mu \mathrm{l}$ of standard/formamide mix and denatured for genotyping. The genotyping results were processed by the GeneMapper v3.7 program which determines the allele sizes in each animal. A total of 140 samples including 40 from BGE, 39 from BGN, 37 from BGC and 24 from GAR were amplified and genotyped.

Table 1. PCR condition used for different microsatellite markers

\begin{tabular}{|c|c|c|c|}
\hline Locus & Size range $(\mathrm{bp})$ & Annealing Tm & $\begin{array}{c}\text { Mg++ } \\
\text { concentration }\end{array}$ \\
\hline OarFCB128 & $80-150$ & $56^{\circ} \mathrm{C}$ & $1.5 \mathrm{mM}$ \\
\hline HUJ616 & $100-175$ & $58^{\circ} \mathrm{C}$ & $1.5 \mathrm{mM}$ \\
\hline OarHH47 & $115-156$ & Touchdown & $1.5 \mathrm{mM}$ \\
\hline SRCRSP5 & $110-170$ & $56^{\circ} \mathrm{C}$ & $1.5 \mathrm{mM}$ \\
\hline MCM527 & $157-200$ & $57^{\circ} \mathrm{C}$ & $1.5 \mathrm{mM}$ \\
\hline ILSTS5 & $155-230$ & $55^{\circ} \mathrm{C}$ & $1.5 \mathrm{mM}$ \\
\hline OAER129 & $120-170$ & Touchdown & $1.5 \mathrm{mM}$ \\
\hline ILSTS11 & $240-310$ & $61^{\circ} \mathrm{C}$ & $1.5 \mathrm{mM}$ \\
\hline DYMS1 & $145-210$ & Touchdown & $1.5 \mathrm{mM}$ \\
\hline BM8125 & $100-140$ & $51^{\circ} \mathrm{C}$ & $1.5 \mathrm{mM}$ \\
\hline OarFCB226 & $110-160$ & $56^{\circ} \mathrm{C}$ & $1.5 \mathrm{mM}$ \\
\hline OarJMP29 & $70-160$ & $56^{\circ} \mathrm{C}$ & $1.5 \mathrm{mM}$ \\
\hline SRCRSP9 & $90-140$ & $56^{\circ} \mathrm{C}$ & $1.2 \mathrm{mM}$ \\
\hline MAF214 & $164-296$ & $58^{\circ} \mathrm{C}$ & $1.5 \mathrm{mM}$ \\
\hline OarCP34 & $100-140$ & Touchdown & $1.5 \mathrm{mM}$ \\
\hline OarFCB304 & $144-200$ & $56^{\circ} \mathrm{C}$ & $1.5 \mathrm{mM}$ \\
\hline MAF209 & $100-140$ & $65^{\circ} \mathrm{C}$ & \\
\hline MAF65 & $110-140$ & Touchdown & \\
\hline
\end{tabular}

\section{Statistical analysis}

The genotyped data were analyzed using Microsatellite Toolkit program (Minch, 1995) to calculate allele frequencies at each locus for each population, average number of alleles per population and heterozygosity values (expected and observed). Dispan program (Ota, 1993) was used to calculate $D_{A}$ genetic distances between the populations and an unweighted pair group-method with arithmetic mean (UPGMA) phylogenetic tree was constructed using the PHYLIP 3.57c package (Felsentein, 1995).

\section{Results and Discussion}

\section{Distribution of alleles and heterozygosity within the populations}

All the sheep populations showed polymorphism for microsatellite markers in the present study. The allele number per locus ranged from 2 to 10 in the four populations. The mean numbers of alleles along with heterozygosity values per population are presented in Table 2. The mean numbers of alleles per population ranged from 4.72 (GAR) to 6.39 (BGN). The average observed heterozygosity values are medium in all populations ranging from 0.5084 to 0.5810 with the lowest in population BGE $(0.5084 \pm 0.0187)$ and the highest in population GAR $(0.5810 \pm 0.0237)$. 
Table 2. Mean number of alleles and heterozygosity for different populations

\begin{tabular}{|c|c|c|c|c|}
\hline Population & Loci type & $\begin{array}{c}\text { Mean allele } \\
\text { number }\end{array}$ & $\begin{array}{c}\text { Expected } \\
\text { heterozygosity }\end{array}$ & $\begin{array}{c}\text { Observed } \\
\text { heterozygosity }\end{array}$ \\
\hline BGC & 18 & $5.50 \pm 1.72$ & $0.6221 \pm 0.0402$ & $0.5616 \pm 0.0192$ \\
\hline BGE & 18 & $5.33 \pm 2.00$ & $0.6402 \pm 0.0383$ & $0.5084 \pm 0.0187$ \\
\hline BGN & 18 & $6.39 \pm 2.06$ & $0.6660 \pm 0.0301$ & $0.5653 \pm 0.0187$ \\
\hline GAR & 18 & $4.72 \pm 1.71$ & $0.6262 \pm 0.0424$ & $0.5810 \pm 0.0237$ \\
\hline
\end{tabular}

Tsunoda et al. (1984) found polymorphism in the four regional populations, i.e. Jessore, Khulna, Mymensingh and Noakhali of Bangladeshi sheep, at the 13 blood protein and enzymes loci. Mukesh et al. (2006) investigated the distribution of alleles and heterozygosity in Garole, Nali and Chokla sheep of India using FAO recommended microsatellite markers. They reported a mean number of alleles for Garole sheep of India as 5.63 which was higher than value of the present study in Bangladeshi Garole (4.72). However, they observed the heterozygosity of Indian Garole breed as 0.59 which was almost similar to Bangladeshi Garole sheep (0.58). They further found mean numbers of alleles in Nali and Chokla sheep of India as 6.27 and 5.63, respectively. These values are almost similar to the present study for the allele numbers in other Bangladeshi sheep populations.

\section{Genetic distances between the populations}

The $D_{A}$ genetic distances between different populations are presented in Table 3 . The highest genetic distance (0.1071) was observed between BGN and GAR and the lowest genetic distance (0.0664) between BGC and BGN. So BGN has the closest genetic relationship with BGC. The genetic relationships among different populations are shown in the phylogenetic dendrogram (Fig. 1) constructed on the basis of $D_{A}$ distances and using the unweighted pair group-method with arithmetic mean (UPGMA).

Table 3. $D_{A}$ genetic distances between sheep populations of Bangladesh

\begin{tabular}{|c|c|c|c|c|}
\hline & BGC & BGE & BGN & GAR \\
\hline BGC & & & & \\
\hline BGE & 0.0666 & & & \\
\hline BGN & 0.0664 & 0.0758 & & \\
\hline GAR & 0.1035 & 0.0812 & 0.1071 & \\
\hline
\end{tabular}

In the phylogenetic dendrogram, sheep populations of Bangladesh were divided into three groups, BGC and BGN clustered in the first group, BGE in the second group and GAR in the third group separately.

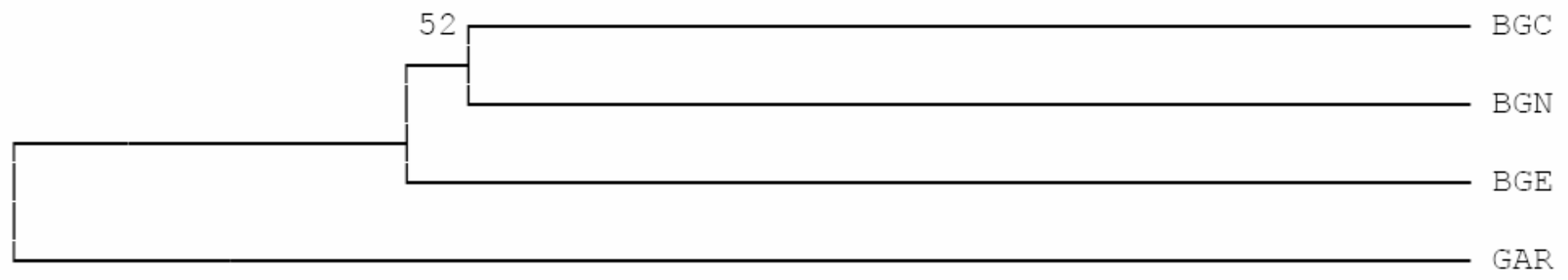

Fig 1. Phylogenetic dendrogram of genetic relationships among four sheep populations. BGC: Bangladeshi central, BGE: Bangladeshi east, BGN: Bangladeshi northern, GAR: Garole sheep in the south west of Bangladesh.

From the history it is evident that BGN was crossed with imported fat-tailed sheep breed of India. On the other hand BGC was crossed with imported breeds Lohi of Pakistan and Romney Marsh, Suffolk and Parendale among others of New Zealand and Australia (Bhuiyan, 2006). Because of the introgression of genes from exotic breeds, BGC and BGN are crossbreds. So BGN and BGC showed a higher mean number of alleles $(6.39 \pm 2.06$ and $5.50 \pm 1.72$, respectively) than GAR and BGE and they grouped in one cluster in the phylogenetic dendrogram. Garole is a renowned breed of sheep and it is found adjacent to Sundarban forest. Sundarban forest is spread over southern Bangladesh and West Bengal of India. 
Phenotypically Garole sheep of Bangladesh is similar to Garole sheep found in West Bengal of India (Sahana et al., 2001). Present genetic studies showed that Garole sheep of Bangladesh has the lowest mean number of alleles $(4.72 \pm 1.71)$ than all other sheep populations (BGC, BGN and BGE) of Bangladesh. Bangladeshi Garole has the same heterozygosity value as the Indian Garole. Genetic distances between Garole and other populations were higher and Garole formed a separate cluster from other populations in the dendrogram. So Garole (GAR) might be considered a separate genetic group i.e. a distinct breed of sheep in Bangladesh.

\section{Conclusion}

It can be concluded that all the populations of sheep in Bangladesh have high genetic diversity with medium heterozygosity. There is significant introgression of genes from exotic breeds in the populations of BGN and BGC than BGE. Garole is distinct from other three populations of sheep as being a distinct breed. The results of the present study would be useful in planning breeding strategy for future genetic improvement program of sheep in Bangladesh.

\section{Acknowledgement}

The authors are grateful to the FAO/IAEA Joint Division Coordinated Research Project (BGD-13005) entitled "Gene-based Technologies in Livestock Breeding: Characterization of Small Ruminant Genetic Resource in Asia" and Bangladesh Agricultural University for financial and technical support to conduct this study. Thanks also to the Officers in Department of Livestock Services for their assistance to collect the data and samples for this study.

\section{References}

Arora, R. and Bhatia, S. 2006. Genetic diversity of Magra sheep from India using microsatellite analysis. Asian Australasian Journal of Animal Sciences, 19(7): pp. 938-942.

BBS, 2004. The Bangladesh Census of Agriculture (Rural) 1996, Structure of Agricultural holdings and livestock population. Bangladesh Bureau of statistics, Dhaka. Vol.1.

Bhuiyan, A.K.F.H. 2006. Livestock genetic resources in Bangladesh: Preservation and Management. International conference on livestock services, Chinese Academy of Agricultural Science (CAAS), Beijing, China, 16-20 April.

FAO Production year book. 2003. vol. 57:210, 231, 216.

Felsenstein, J. 1995. PLYLIP phylogeny software version 3.7c. Department of Genetics, Uniersity of Washington, Seattle, Washington.

Forbes, S. H., Hogg, J. T., Buchanan, F. C., Crawford, A. M., and Allendorf, F. W. 1995. Microsatellite evolution in congeneric mammals: Domestic and big horn sheep. Molecular Biology and Evolution, 12:1106-1113.

Grigaliunaite, I., Tapio, M., Viinalass, H., Grislis, Z., Kantanen, J. and Miceikiene, I. 2003. Microsatellite variation in the Baltic sheep breeds. Veterinarija ir Zootechnika, (21): 66-73.

IAEA. 2004. Hand book on FAO/IAEA inter-regional training course on molecular methods in livestock genetics and breeding. International Atomic Energy Agency Laboratory, Seibergdorf, Austria, June 14-25, 2004.

Minch, E., Ruiz-Linares, A., and Goldstein, D.B. 1995. Microsat (version 1.5d): a program for calculating statistics on microsatellite allele data.

Mukesh, M., Sodhi, M. and Bhatia, S. 2006. Microsatellite based diversity analysis and genetic relationships of three Indian sheep breeds. Journal of Animal Breeding and Genetics, 123(4): pp. 258-264.

Ota, T. 1993. DISPAN: Genetic distance and phylogenetic Analysis. Pennsylvania State University, University Park, PA.

Radko, A., Rychlik, T. and Sota, E. 2006. Genetic characterization of the Wrzosowka sheep breed on the basis of 14 microsatellite DNA markers. Medycyna Weterynaryjna, 62(9): pp. 1073-1075.

Rahman, M.M. 1989. Sheep production and development in Bangladesh. In: Sheep Production in Asia.Proc. of the Workshop on Sheep Production in Asia. PCARRD, Los Banos, Laguna, The Philippines, ed. C. Davendra and P.S. Faylon, IDRC. pp. 81-95.

Sahana, G., Gupta, S.C. and Nivsarkar, A.E. 2001. Garole: The prolific sheep of India. Animal Genetic Resources Information, 31: pp. 55-64.

Tsunoda, K., Amano, T., Katsumata, M., Nozawa, K., Namikawa, T., Tsubota, Y., Hasnath, M.A., Mostafa, K.G. and Faruque, M.O. 1984. Morphological Characters and Blood Protein Polymorphisms in the Sheep of Bangladesh. Genetics Studies on Breed Differentiation of Native Domestic Animals in Bangladesh. Tokyo University of Agriculture, pp. 57-85. 